\title{
GEODINAMIKA KAWASAN TIMUR INDONESIA DAN IMPLIKASINYA TERHADAP POTENSI SUMBER DAYA DASAR LAUT
}

\section{GEODYNAMIC OF THE EASTERN REGION OF INDONESIA AND IMPLICATION TO THE SEAFLOOR RESOURCES POTENCY}

\author{
Rainer Arief Troa, Eko Triarso, dan Ira Dillenia \\ Pusat Penelitian dan Pengembangan Sumberdaya Laut dan Pesisir, \\ Badan Penelitian dan Pengembangan Kelautan dan Perikanan, Kementerian Kelautan dan Perikanan RI \\ Kompleks Bina Samudera Gd.II Balitbang KP Lt.4, J1. Pasir Putih II Ancol Timur, Jakarta 14430 \\ Telp: (021) 64700928, 64700755 Ext : 3118, Faks: (021) 64711654 \\ Email: renertroa@gmail.com
}

Diterima tanggal:31 Oktober 2016, diterima setelah perbaikan: 30 Januari 2017disetujui tanggal:13 Februari 2017

\begin{abstract}
ABSTRAK
Kawasan Timur Indonesia menyimpan potensi sumber daya dasar laut yang tinggi. Interaksi tiga lempeng besar dunia: Lempeng Pasifik, Hindia-Australia, dan Eurasia menjadikan kondisi geodinamikanya aktif dan kompleks. Tujuan penulisan untuk mengungkap potensi sumber daya dasar laut sebagai implikasi kondisi geodinamika. Metode penelitian menggunakan analisis tektonika berdasarkan tinjauan regional evolusi tektonik yang ditunjang metode tomografi seismik dengan hipotesis bahwa potensi sumber daya dasar laut sebagai implikasi kondisi geodinamikanya berkaitan erat dengan keberadaan gunungapi bawah laut dan aktivitas hidrotermal. Hasil penelitian menunjukkan potensi tersebut berada pada zona aliran fluida magma di bawah kerak bumi, diindikasikan anomali kecepatan rendah gelombang-S pada tomogram seismik. Hasil pengamatan ROV di Perairan Sangihe-Talaud mengindikasikan adanya peluruhan sebagian magma menerobos kerak bumi, muncul ke permukaan dasar laut membentuk cerobong hidrotermal gunungapi bawah laut Kawio Barat pada kedalaman 1890 meter. Di perairan dangkal Halmahera, manifestasi aktivitas hidrotermal berupa semburan air panas dari dasar laut. Di dataran pasang surut, temperatur mata air panas mencapai $80-100^{\circ} \mathrm{C}$, sedangkan dari tipe alterasi batuannya diindikasikan temperatur bawah permukaan $>200^{\circ} \mathrm{C}$. Disimpulkan bahwa potensi sumber daya dasar laut terkait aktivitas hidrotermal dan gunungapi bawah laut di perairan Sangihe-Talaud adalah berasosiasi dengan mineralisasi logam pada cerobong hidrotermal. Di Halmahera, potensinya berupa uap panas hidrotermal yang dapat dimanfaatkan untuk energi terbarukan berbasis panas bumi. Implikasi kebencanaan juga melekat akibat kondisi geodinamika sehingga penelitian mitigasi bencana dan model adaptasinya disarankan dilakukan juga pada Kawasan Timur Indonesia.
\end{abstract}

Kata kunci: Kawasan Timur Indonesia, geodinamika, tomografi seismik, sumber daya dasar laut, aktivitas hidrotermal

\section{ABSTRACT}

Eastern Indonesia Region holds the high potential of the seafloor resources. Triple junction of the Pacific Plate, Indian-Australian, and Eurasian caused the active geodynamics. The purpose to reveal the potency of seafloor resources as an implication of its geodynamics. The methods use analysis of tectonic evolution and tomography. As the hypotheses, the potency was related to the submarine volcano and hydrothermal activities. The result showed the potency located at the magma fluid zone beneath earth's crust indicated by $S$-wave low velocity on tomogram. The ROV observation in Sangihe-Talaud indicated the partial melting of magma breaking through the seafloor and forming chimney of Kawio Barat at 1890 meters depth. In the Halmahera's shallow waters, presence as submarine geyser. At the intertidal plain, the hotsprings temperature reached 80 $100^{\circ} \mathrm{C}$, while rock alteration indicated the subsurface $>200^{\circ} \mathrm{C}$. It was concluded the potency associated with mineralization as revealed in Sangihe Talaud. In Halmahera, it was associated with geyser and the utilization based on geothermal energy is well recommended. The geodynamic condition has also disaster implication, then the related study is also suggested in the region.

Geodinamika Kawasan Timur Indonesia Dan Implikasinya Terhadap Potensi Sumber Daya Dasar Laut Rainer Arief Troa, Eko Triarso, dan Ira Dillenia 
Keywords: Eastern Indonesia Region, geodynamic, seismic tomography, seafloor resources, hydrothermal activity

\section{PENDAHULUAN}

Potensi sumber daya dasar laut (seafloor resources) adalah berkaitan erat dengan pergerakan lempeng tektonik bumi yang dinamis. Konsep klasik tentang tatanan tektonik lempeng dunia (plate tectonic) yang berkembang pada pertengahan abad ke-20, pada saat ini semakin diperkaya dengan perkembangan teknologi instrumentasi kelautan abad ke-21. Kecepatan pergerakan tunjaman antar lempeng pun dapat ditentukan secara kuantitatif seperti hasil analisis tektonika menurut Hall (2008). Hasil analisis ini menunjukkan bahwa di Kawasan Samudera Hindia Perairan Barat Sumatera dan Selatan Jawa terjadi pergerakan tunjaman Lempeng Samudera Hindia ke bawah Lempeng Eurasia dengan kecepatan mencapai $7 \mathrm{~cm}$ pertahun ke arah utara-timur laut. Sedangkan pada Kawasan Timur Indonesia, dipengaruhi pergerakan penunjaman Lempeng Laut Filipina ke bawah Lempeng Benua Eurasia yang memiliki kecepatan $10 \mathrm{~cm}$ pertahun berarah barat laut. Di bagian lain, interaksi Lempeng Benua Australia dan Lempeng Samudera Pasifik memiliki kecepatan tunjaman $11 \mathrm{~cm}$ pertahun ke arah timur laut. Interaksi antar lempeng tektonik dan arah vektor pergerakannya dapat dilihat pada Gambar 1.

Kawasan Timur Indonesia ditempati dua pulau besar yaitu Sulawesi dan Papua, serta gugusan pulau kecil terdiri dari Kepulauan Banda Selatan, Kepulauan Sunda Kecil (Nusa Tenggara), Maluku, dan Halmahera. Geodinamika pada Kawasan Timur Indonesia kondisinya sangat kompleks dengan terjadinya interaksi tiga lempeng besar dunia yaitu Lempeng Samudera Pasifik, Lempeng HindiaAustralia, dan Lempeng Benua Eurasia yang terkenal dengan nama Triple Junction. Penunjaman Lempeng Pasifik ke arah barat daya mendesak Lempeng Hindia-Australia di bagian selatannya yang juga bergerak ke arah timur laut mengakibatkan terbentuknya Palung Nugini tepat di bawah perairan utara Papua. Lempeng Hindia-Australia bergerak dari selatan menunjam ke arah barat laut pada sisi selatan Kawasan Laut Banda dan berputar arah membentuk huruf u (u-turn) di sekitar deretan kepulauan Banda, menunjam ke barat daya membentuk palung di utara Pulau Seram dan Pulau Buru. Di sisi timurnya, akibat interaksi Lempeng Australia dan Lempeng Pasifik memicu terjadinya patahan aktif Sesar Sorong yang bergerak mendatar dari timur ke barat tepat di Kawasan Kepala Burung Papua dan mendorong Kepulauan Banggai-Sula mendekati perairan Sulawesi Timur. Lempeng Eurasia sendiri yang secara tektonik relatif stabil, didesak terus di bagian selatannya oleh tunjaman Lempeng Samudera Hindia di bawah Perairan Selatan Jawa-Lombok-Sumba dan penunjaman Lempeng Hindia-Australia di sekitar Laut Banda.

Begitu pula di bagian utara Kawasan Timur Indonesia, terjadi interaksi Lempeng Samudera Pasifik, Lempeng Laut Filipina, Lempeng Laut Maluku, dan Lempeng Laut Sulawesi. Jadi cukup jelas terlihat bahwa Kawasan Timur Indonesia memang memiliki kondisi geodinamika yang sangat aktif. Kondisi aktif tersebut memicu tingkat seismisitas menjadi tinggi yang mengakibatkan potensi gempa bumi akan intensif terjadi pada kawasan ini. Menurut Simandjuntak (2004), kondisi geodinamika aktif juga membentuk deretan gunungapi di sepanjang zona penunjaman tersebut yang terbagi ke dalam jalur-jalur orogenesa gunungapi. Menurut Troa et al. (2007) melalui hasil interpretasi tomogram seismik, jalur orogenesa terpenting yang potensial memiliki sumber daya dasar laut melimpah adalah pada Orogenesa Banda di bagian selatan dan Orogenesa Talaud di bagian utara. Pada bagian selatan Kawasan Timur Indonesia yang berkaitan dengan jalur Orogenesa Banda, telah dibuktikan potensinya melalui Ekspedisi Bandamin 2002 - 2004 dengan menemukan indikasi keterdapatan mineral hidrotermal bawah laut di sekitar Gunungapi Bawah Laut Abangkomba (Halbach et al., 2003; Sarmili et al., 2003). Mineralisasi ini terbentuk melalui genetika pembentukan mineral secara epitermal sulfidasi rendah (Makarim, 2005). Berdasarkan model konseptual alterasi dan mineralisasi, ditemukan tipe mineralisasi 


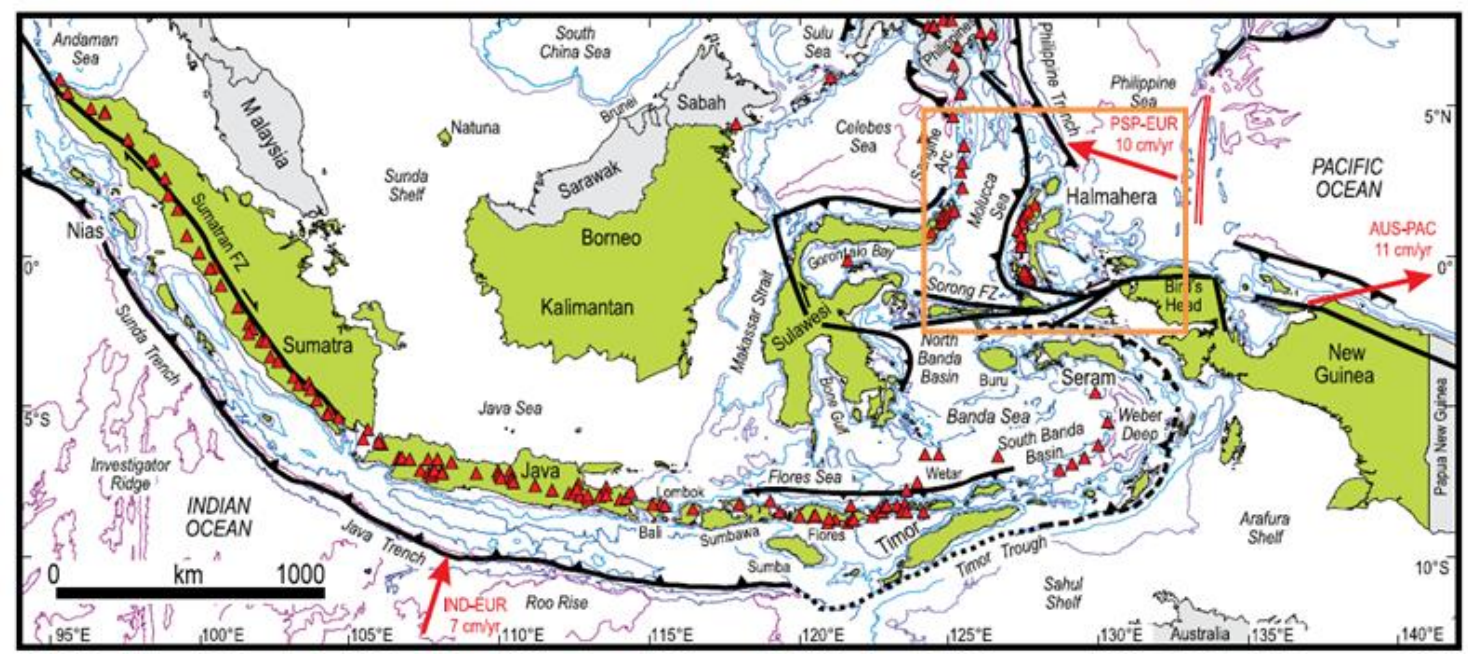

Gambar 1. Gambaran rupa bumi Indonesia pada saat sekarang yang memperlihatkan batasbatas tektonika dan jalur gunungapi. Kontur batimetri menunjukkan kedalaman 200 m, 1000 m, 3000 m, 5000 m, 6000 m. Panah warna merah menunjukkan arah dan kecepatan pergerakan konvergensi lempeng benua

Figure 1.The map of Indonesia showed the tectonic boundaries and the volcanoes zone. Bathymetri contour described the depth of $200 \mathrm{~m}, 1000 \mathrm{~m}, 3000 \mathrm{~m}, 5000 \mathrm{~m}, 6000 \mathrm{~m}$. The arrow sign showed the heading and speed of continental motion tectonic plate

(Sumber peta: Hall, 2008).

volcanogenic massive sulfida pada genetika epitermal sulfidasi rendah tersebut (Troa, et al., 2009).

Pada bagian utara Kawasan Timur Indonesia, eksplorasi untuk pembuktian keberadaan sumber daya dasar laut secara visual berteknologi tinggi dilakukan pada tahun 2010 melalui Ekspedisi INDEX-SATAL. Sebelumnya, indikasi keberadaan sumber daya tersebut diketahui pada Ekspedisi IASSHA 2003 melalui conto batuan hasil pengerukan (dredge sample) dan anomali CTD di sekitar perairan Sangihe-Talaud (Mc.Conachy et al., 2003; Permana et al., 2003). Di samping itu, potensi besar sumber daya yang masih berkaitan secara geodinamika adalah pada kawasan perairan Halmahera yang terletak di sebelah timur dari perairan Sangihe-Talaud. Dalam tulisan ini, pokok bahasan difokuskan pada bagian utara Kawasan Timur Indonesia tersebut, tepatnya berada di Perairan SangiheTalaud dan Halmahera (Gambar 1, pada kotak oranye). Tujuan penulisan ini adalah untuk mengungkapkan potensi sumber daya dasar laut yang merupakan implikasi dari kondisi geodinamika Kawasan Timur Indonesia secara deskriptif-analitis terutama pada Perairan Sangihe-Talaud dan Halmahera.

\section{BAHAN DAN METODE}

Sistematika atau alur berpikir dalam penulisan ini mengikuti kaidah terapan ilmu geologi dan geofisika dalam melakukan studi eksplorasi sumber daya kebumian. Pada awalnya dilakukan tinjauan regional evolusi tektonik Kawasan Timur Indonesia berdasarkan data sekunder, teori tektonika, hingga hasil riset terkait di lokasi penelitian, serta ditunjang metode tomografi seismik. Kemudian, ditarik hipotesis bahwa potensi sumber daya dasar laut sebagai implikasi kondisi geodinamika Kawasan Timur Indonesia adalah berkaitan erat dengan keberadaan gunungapi bawah laut dan aktivitas hidrotermal yang juga ditunjukkan oleh zona anomali kecepatan rendah (low velocity zone) pada tomogram gelombang-S (secondary atau shear wave). Bahan yang digunakan untuk menghasilkan tomogram seismik 3D adalah dari katalog gempa Engdahl, dengan model referensi struktur kecepatan 1D ak135, blok model (lintang, bujur, kedalaman) $0,5^{\circ} \times 0,5^{\circ} \times 35 \mathrm{~km}$, ray tracing pseudo bending, dengan metode inversi non linier least square. Pembuktian potensi diungkapkan pada kegiatan ekspedisi laut dalam dan survey lapangan yang dilakukan dari tahun 2010 hingga 2013 di perairan

Geodinamika Kawasan Timur Indonesia Dan Implikasinya Terhadap Potensi Sumber Daya Dasar Laut - 
Sangihe-Talaud dan Halmahera. Tahun 2010, berhasil diungkapkan melalui metode pemetaan batimetri resolusi tinggi hingga 30 arc-second menggunakan multibeam echosounder Kongsberg EM-302 dan liputan bawah laut menggunakan Remotely Operated Vehicle (ROV) "Little Hercules" di perairan laut dalam Sangihe-Talaud bekerjasama dengan NOAA Amerika Serikat pada Ekspedisi INDEX-SATAL menggunakan kapal Okeanos Explorer (Triarso, 2010). Tahun 2011, berhasil dipetakan kondisi geodinamika, penyebaran gunungapi dan aktivitas hidrotermal di kawasan perairan dangkal (shallow waters) Halmahera menggunakan metode analisis morfostruktur (Triarso, 2011). Metode observasi lapangan dan penyelaman dilakukan pada tahun 2012 dan 2013. Tahun 2012, ditemukan indikasi aktivitas hidrotermal di kawasan barat Pulau Halmahera (Troa, 2012). Tahun 2013, ditemukan aktivitas hidrotermal di kawasan pantai dan perairan Halmahera Selatan (Troa, 2013). Model pemanfaatan aktivitas hidrotermal untuk energi listrik terbarukan dilakukan secara konseptual dengan memanfaatkan aliran konveksi dari semburan air panas di perairan dangkal Halmahera. Bentuk tindak lanjut dari mitigasi dan adaptasi kebencanaan terkait kondisi geodinamika aktif adalah konsep penggunaan Anchor Reinforcement pada model preservasi insitu sumber daya arkeologi maritim yang posisinya berada pada kelerengan dasar laut dengan kondisi geodinamika kawasan yang aktif (Dillenia et al., 2016).

\section{HASIL DAN PEMBAHASAN}

\section{Evolusi Tektonik Kawasan Timur Indonesia}

Kawasan Timur Indonesia terbentuk melalui proses geologi yang sangat kompleks akibat dari konvergensi tiga lempeng utama yaitu Lempeng Benua Eurasia yang relatif stabil, Lempeng Samudera Pasifik yang bergerak relatif ke barat, dan Lempeng Benua Australia yang bergerak relatif ke utara. Pergerakan Lempeng Eurasia sejak 100 juta tahun yang lalu hingga sekarang telah mengalami perputaran searah jarum jam. Penelitian mengenai pergerakan lempeng berdasarkan keberadaan hotspot di bawah permukaan bumi, membuktikan bahwa pada sekitar 55 - 60 juta tahun yang lalu sampai dengan sekarang lempeng ini berputar searah jarum jam sebesar $100^{\circ}$ (Morgan, 1980 dalam Daly et al., 1987).

Lempeng Australia merupakan hasil pecahan dari Benua Antartika pada zaman Kapur Tengah yang pada masa awal pembentukannya bergerak mengarah ke timur, tetapi sekitar 45 50 juta tahun yang lalu pergerakan lempeng ini mengalami perubahan menjadi bergerak relatif mengarah utara secepat terjadinya pemekaran lantai dasar samudera (oceanic-floor spreading) yang terjadi di selatan Samudera Hindia. Pergerakan ini juga yang mempengaruhi terjadinya tumbukan antar benua yaitu antara India dengan Asia Tenggara. Pergerakan mengarah ke utara pada zaman Kenozoikum terlihat dengan ditemukannya liniasi magnetik lantai samudera (seafloor magnetic lineations) di selatan Samudera Hindia (Daly et al., 1987). Pada akhir Paleosen atau Eosen Awal hingga Eosen Tengah - Akhir, Lempeng Australia bergeser ke utara - timur laut secara menerus hingga sekarang dengan kecepatan $12 \mathrm{~mm}$ hingga 83 mm pertahun (Lee \& Lawver, 1995; Hall, 2002; Permana, 2002). Subduksi ke selatan dari Kerak Samudera Pasifik terhadap Lempeng Australia yang telah berlangsung sejak Mesozoikum menghasilkan sistem busur gunungapi Tersier di utara Sula, Buton, dan Kepala Burung Papua yang pada masa itu masih merupakan bagian dari Lempeng Kontinen Australia (Gambar 2). 


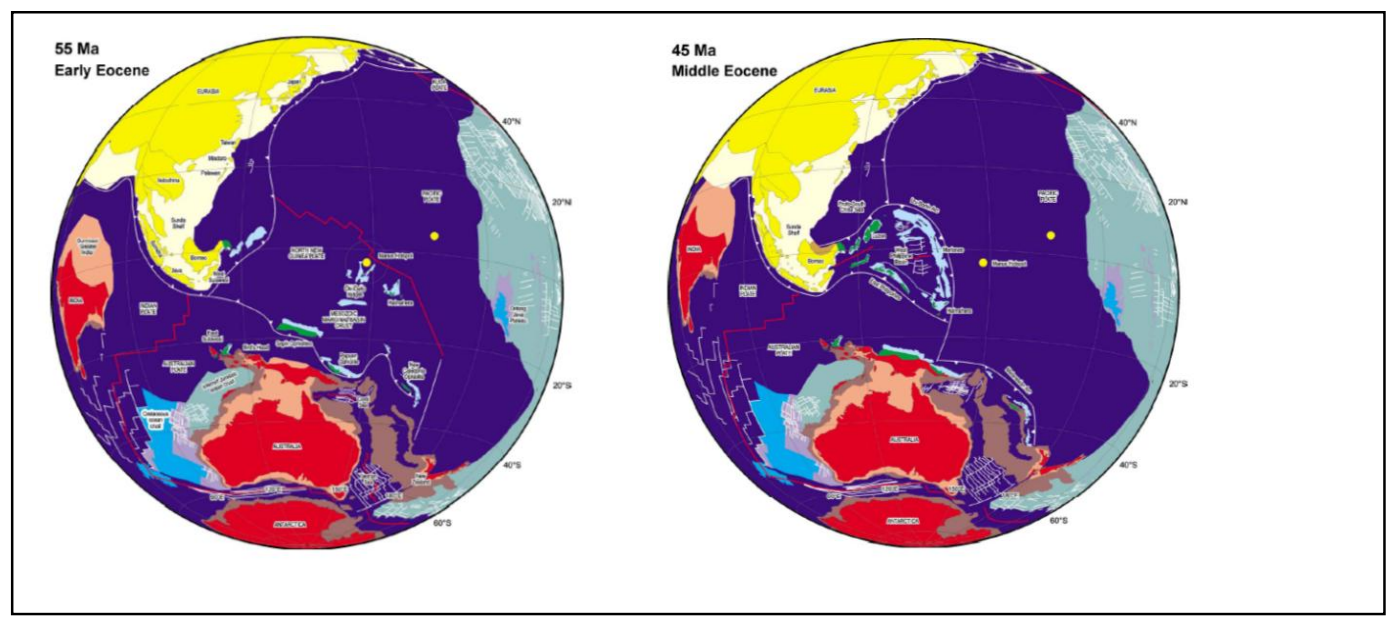

Gambar 2. Tektonika lempeng bumi yang membentuk kawasan timur Indonesia pada 55 juta tahun yang lalu (Eosen Awal) dan 45 juta tahun yang lalu (Eosen Tengah);

Figure 2. Earth's tectonic plates had shaped the eastern Indonesia since 55 million years ago (the Early Eocene) and 45 million years ago (Middle Eocene)

sumber: Hall (2002)

Pada Kala Miosen (23 - 5 juta tahun lalu), Kawasan Timur Indonesia mulai menunjukkan bentuk sebagai hasil interaksi tiga lempeng utama dengan peristiwa geologi yang terjadi berupa terbentuknya zona bukaan dan pembentukan ofiolit Neogen di utara Timor dalam lingkungan punggungan tengah samudera, serta ofiolit Neogen di bagian barat Seram terbentuk dalam konteks busur belakang. Pada Miosen Awal (Gambar 3), terjadi tabrakan miring antara Lempeng Australia dan Lempeng Pasifik, Filipina, dan

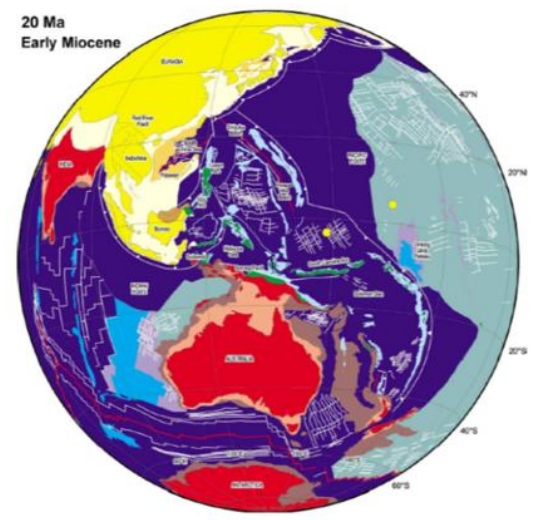

Carolina membentuk sesar-sesar mendatar sinistral dan menyebabkan terfragmentasinya bagian Kepala Burung Papua, menghasilkan beberapa lempeng mikrokontinen Australia (New Guinea) ditandai oleh pemalihan regional akibat obduksi serta anjakan busur muka terhadap busur vulkanik diikuti anjakan busur belakang ke utara dan menutupnya cekungan busur belakang pada Miosen Tengah serta anjakan ofiolit di barat Seram (Lee \& Lawver, 1995; Hall, 2002; Permana, 2002). Pada akhir Miosen ditandai dengan rotasi

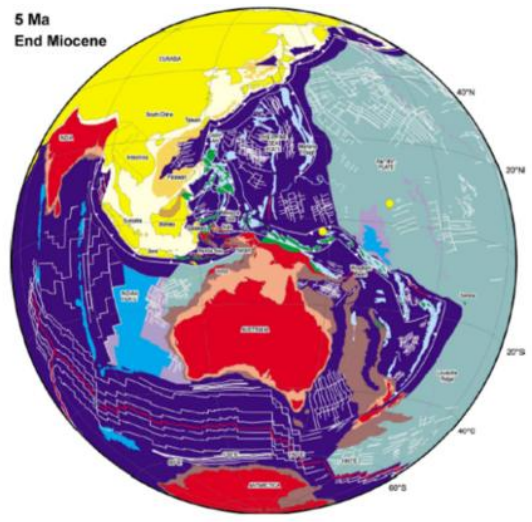

Gambar 3. Tektonika lempeng bumi yang membentuk kawasan timur Indonesia pada 20 juta tahun (Miosen Awal) dan 5 juta tahun yang lalu (Miosen Akhir);

Figure 3. Earth's plate tectonic had shaped the eastern Indonesia since 20 million years ago (Early Miocene) and 5 million years ago ( Late Miocene) sumber: Hall (2002).

Geodinamika Kawasan Timur Indonesia Dan Implikasinya Terhadap Potensi Sumber Daya Dasar Laut - 
berlawanan arah jarum jam dari Pulau Seram menempati posisinya sekarang diikuti oleh obduksi Ofiolit dan pemalihan pada lempeng mikro Seram (Gambar 3). Pada Kala Pliosen (5 - 2 juta tahun yang lalu), terjadi penunjaman ke utara dari kerak benua Australia dan ditandai oleh aktivitas gunungapi di sekitar busur Banda Selatan, Buru, dan Seram. Pada Kala Resen atau kondisi saat sekarang, Lempeng Pasifik bergeser ke arah barat-barat daya dengan kecepatan 95-100 mm pertahun, sementara Lempeng Australia bergerak ke arah utara-timur laut dengan kecepatan $72 \mathrm{~mm}$ pertahun (Benes \& Scot, 1994; Hall, 2002; Wilson, 2002; Permana, 2002).

\section{Potensi Sumber Daya Dasar Laut}

Berdasarkan tinjauan regional evolusi tektonik Kawasan Timur Indonesia pada sub bahasan sebelumnya, ditunjukkan bahwa implikasi kondisi geodinamika aktif ini adalah terbentuknya busur gunungapi aktif di sepanjang jalur interaksi antar lempeng. Keterdapatan gunungapi bawah laut dan aktivitas hidrotermal berimbas kepada kelimpahan potensi sumber daya dasar laut yang berasosiasi dengannya. Jadi, potensi sumber daya dasar laut (seafloor resources) kawasan ini memiliki keterkaitan erat dengan evolusi tektonik dan orogenesa gunungapi pada jajaran kepulauan di sebelah tenggara dan timur dari busur kepulauan Sunda-Banda bagian dalam hingga ke utara melewati Kepulauan Sangihe-Talaud dan Halmahera yang merupakan jalur gunungapi Resen. Sedangkan aktivitas hidrotermal bawah laut yang terjadi saat ini, berhubungan dengan kegiatan magmatisme akhir dari gunungapi tersebut. Sumber panas magma di bawah permukaan mengintrusi air laut yang masuk ke dalam batuan induk berpermeabilitas tinggi yang mengubah komposisi kimia batuannya (Corbett dan Leach, 1996).

Di bagian utara Kawasan Timur Indonesia yang merupakan fokus lokasi pembahasan dalam tulisan ini, tatanan tektonik yang memicu pembentukan gunungapi bawah laut dan aktivitas hidrotermal adalah akibat tumbukan ganda busur kepulauan (double-arc collision) di sekitar Lengan Timur Sulawesi dan Halmahera. Tumbukan ganda tersebut terjadi antara Lempeng Laut Sulawesi dan
Lempeng Laut Maluku pada selubung bumi bagian atas di perairan Sangihe-Talaud dan Halmahera. Berdasarkan hasil analisis tomografi seismik kecepatan gelombang $\mathrm{P}$ (Vp), ditunjukkan bahwa struktur selubung bumi bagian atas yang membentuk tumbukan ganda (double-arc collision) tersebut sangat aktif yang dicirikan oleh nilai rendah $\mathrm{Vp}$ atau nilai negatif berwarna merah seperti tertera pada Gambar 4.

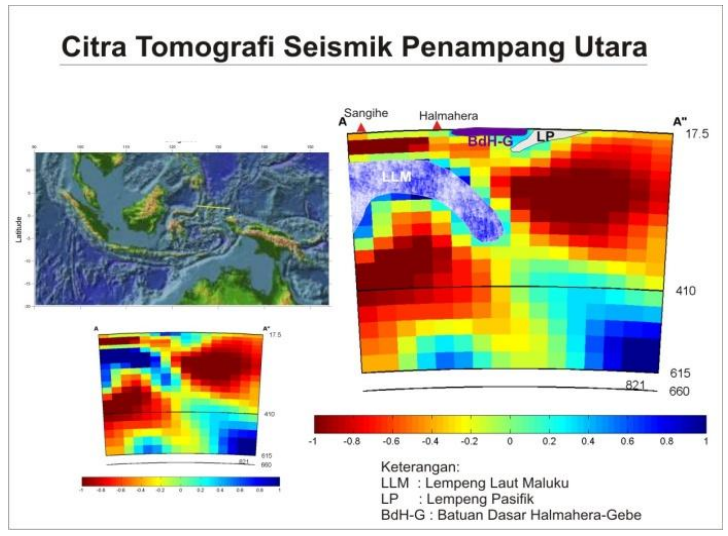

Gambar 4. Penampang tomografi seismik struktur selubung bumi bagian atas yang membentuk tumbukan ganda (double-arc collision)

berdasarkan citra tomografi kecepatan gelombang $\mathrm{P}(V p)$;

Figure 4. Seismic tomography section of upper mantle esthablishing double-arc collision based on tomographic imaging of $P$ wave velocity sumber: hasil pengolahan data.

Secara pelamparan horisontal pada kawasan perairan Sangihe-Talaud dan Halmahera, ditunjukkan melalui hasil analisis tomografi seismik kecepatan gelombang S seperti tertera pada Gambar 5. Dari gambar tersebut terlihat bahwa anomali kecepatan rendah (low velocity zones) yang ditunjukkan dengan warna merah pada peta, penyebarannya mengikuti pola tunjaman dan struktur geologi yang berkembang pada kawasan tersebut. Zonasi anomali kecepatan rendah ini dapat dicitrakan dengan baik pada tomogram gelombang $\mathrm{S}$ karena karakteristik gelombang $\mathrm{S}$ yang sangat sensitif terhadap rigiditas atau modulus geser suatu batuan, artinya nilai kecepatan gelombang $\mathrm{S}$ akan turun drastis atau mendekati nilai nol bila melewati medium cair (fluid) sehingga pembatasan zona padat (solid) dan 
cair (fluid) di bawah permukaan bumi menjadi lebih tegas. Zona padat mewakili batuan kerak bumi, sedangkan zona cair mewakili fluida magma di selubung bumi bagian atas. Magma inilah yang menjadi sumber panas dalam pembentukan gunungapi bawah laut dan aktivitas hidrotermal. Pola zonasi aliran fluida magma di bawah kerak bumi Perairan SangiheTalaud dan Halmahera ditunjukkan pada kotak A1 dalam Gambar 5.

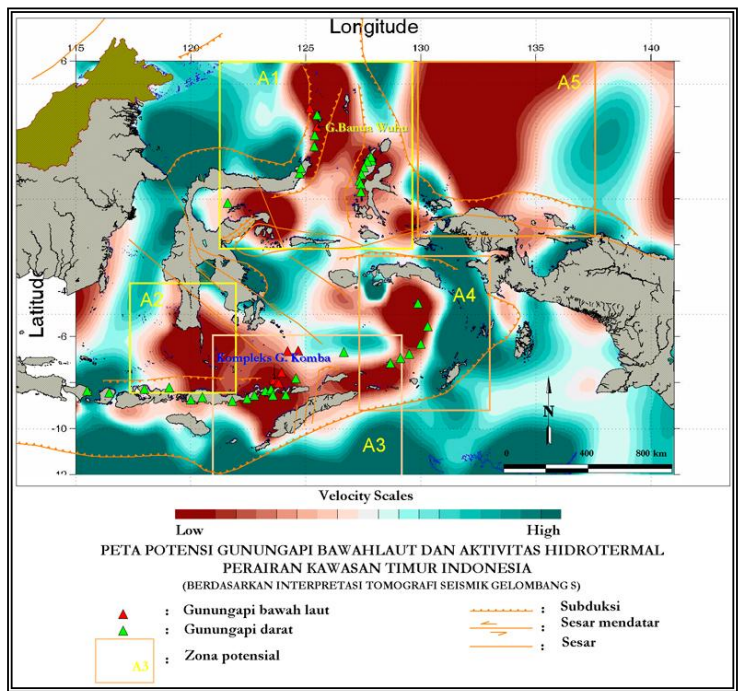

Gambar 5. Peta Potensi Gunungapi Bawah Laut dan Aktivitas Hidrotermal Perairan Kawasan Timur Indonesia (berdasarkan interpretasi tomografi seismik kecepatan gelombang S); Figure 5. Map of submarine volcanoes and hydrotermal activities in the eastern of Indonesian Waters (based on seismic tomographic interpretation of $S$ wave velocity sumber: pengolahan data.

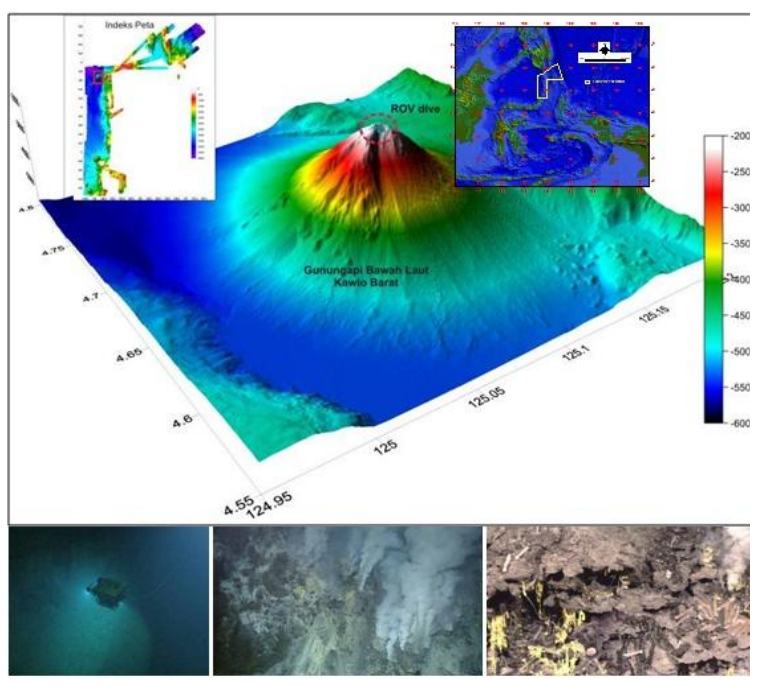

Gambar 6. Hasil pemetaan dasar laut dalam beresolusi tinggi gunungapi bawah laut Kawio

Barat (gambar atas) dan rekaman gambar sumberdaya aktivitas hidrotermal disekitarnya menggunakan ROV yang berhasil diungkapkan pada Ekspedisi INDEX-SATAL 2010 (gambar bawah);

Figure 6. The result of of Kawio Barat's submarine volcanoe mappingwith high resolution (the above picture) and the recording picture of the hydrotermal activities using ROV which was successful disclosed on INDEX-SATAL 2010

Expedition ( the below picture) sumber: hasil pengolahan data.

Pembuktian secara visual keberadaan sumber daya dasar laut pada tomogram seismik tersebut dilakukan pada kegiatan ekspedisi laut dalam INDEX-SATAL tahun 2010. Hal ini cukup beralasan, mengingat untuk melakukan riset dan eksplorasi laut dalam dibutuhkan teknologi tinggi dengan biaya sangat besar yang hanya bisa dilakukan melalui kerjasama riset dengan pihak asing. Pada pelaksanaan ekspedisi kelautan tersebut, Perairan SangiheTalaud dipetakan secara detail seluas \pm 38.549 $\mathrm{km}^{2}$ perairan laut dalam di sekitar kawasan Perairan Sangihe-Talaud (Gambar 6). Rekaman video dan gambar berdefinisi tinggi (high definition camera) dari aktivitas hidrotermal (hydrothermal vent) pada gunungapi bawah laut Kawio Barat berhasil diambil menggunakan ROV dan merupakan data pertama, bahkan mungkin satu-satunya hingga saat ini sebagai rujukan data primer untuk kondisi bawah laut dari kawasan ini. Dari hasil liputan bawah laut tersebut, ditunjukkan bahwa kondisi batuan mengalami proses alterasi dan mineralisasi di sekitar cerobong hidrotermal (chimney). Artinya, gunungapi bawah laut Kawio Barat diindikasikan berasosiasi dengan mineral logam.

\section{Pemanfaatan Sumber Daya Dasar Laut dan Adaptasi Kebencanaan}

Salah satu sumber daya aktivitas hidrotermal bawah laut di Kawasan Timur Indonesia adalah di perairan barat Halmahera. Sumber daya ini tersebar pada wilayah pantai pasang surut hingga perairan dangkal (shallow waters). Aktivitas hidrotermal akan berada di bawah permukaan laut pada saat air laut pasang. Umumnya berupa mata air dan uap panas yang 
muncul dalam retakan batuan. Berdasarkan tipe alterasi lempungan dan asosiasi mineral ubahannya, temperatur fluida hidrotermal dapat mencapai lebih dari $200{ }^{\circ} \mathrm{C}$. Manifestasi di permukaan bertemperatur lebih rendah yaitu sekitar $80-100{ }^{\circ} \mathrm{C}$. Artinya, sumber daya aktivitas hidrotermal menyimpan potensi untuk dikembangkan menjadi sumber daya energi baru terbarukan dengan memanfaatkan uap panas bertemperatur tinggi yang masih tersimpan di bawah permukaan.

Demikian pula di perairan dangkal, semburan air panas hidrotermal dari dasar laut yang memiliki tekanan atau gaya dorong ke atas cukup kuat memiliki potensi pemanfaatan menjadi sumber energi terbarukan berbasis hidrotermal bawah laut (shallow waters hydrothermal). Secara skematik, bentuk pemanfaatan sumber daya aktivitas hidrotermal bawah laut dapat dilihat dalam Gambar 7. Prinsip kerjanya adalah semburan air panas bertemperatur tinggi di dasar laut akan memberikan aliran konveksi panas ke dalam pipa, sehingga uap panas yang dihasilkan akan menggerakkan turbin yang menghasilkan energi listrik. Sumber daya hidrotermal bawah laut tersebut dapat berpotensi untuk menjadi sumber daya kelautan di masa depan (future marine resources).

Bentuk tindak lanjut dari mitigasi dan adaptasi kebencanaan terkait kondisi geodinamika aktif adalah konsep penggunaan Anchor Reinforcement pada model preservasi insitu sumber daya arkeologi maritim yang posisinya berada pada kelerengan dasar laut dengan kondisi geodinamika kawasan yang aktif (Gambar 8). Model ini merupakan rekomendasi hasil penelitian arkeologi maritim tahun 2014 (Dillenia et al., 2016) pada situs Pesawat Perang Dunia II yang tenggelam di Perairan Raja Ampat, Papua Barat. Ditinjau dari kondisi geodinamika, kawasan kepala burung Papua memang potensial terkena bencana terkait pergerakan patahan aktif Sesar Sorong yang melintasi perairan tersebut. Situs ini telah dimanfaatkan sebagai obyek wisata bahari yang sangat ramai dikunjungi para wisatawan dan penyelam domestik dan mancanegara, sehingga dampak bencana yang ditimbulkan harus direduksi semaksimal mungkin karena telah menjadi sumber pendapatan bagi pemerintah daerah setempat dan masyarakat sekitarnya.

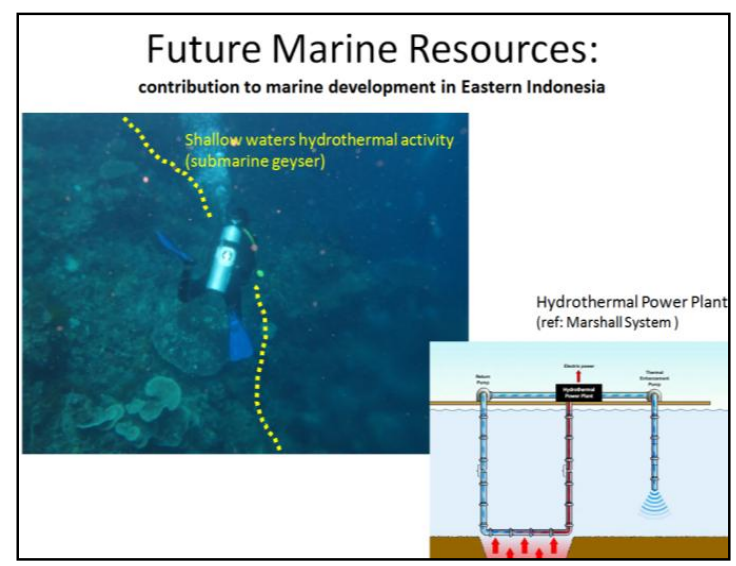

Gambar 8. Potensi sumber daya kelautan masa depan shallow waters hydrothermal;

Figure 8. Shallow waters hydrothermal for the future potential of marine resource

Sumber: modifikasi dari Marshall System

Hydrothermal Power Plant dalam Troa et al. (2012)

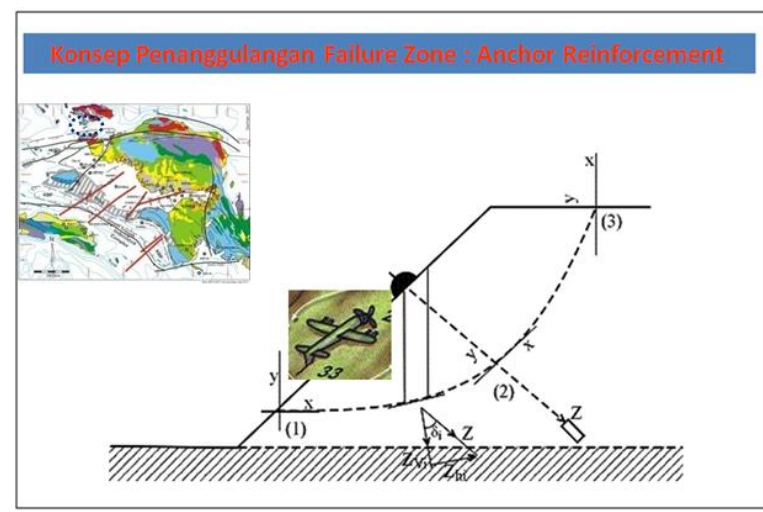

Gambar 9. Konsep penggunaan Anchor Reinforcement pada sumber daya arkeologi laut; Figure 9. Anchor Reinforcement concept for marine archaeological resource

sumber: hasil pengolahan data Dillenia et al. (2014) dalam Dillenia et al. (2016)

\section{KESIMPULAN DAN SARAN}

Kawasan Timur Indonesia memiliki kondisi geodinamika aktif dan merupakan kunci bagi pengungkapan tatanan tektonik secara global. Potensi sumber daya dasar laut sebagai implikasi kondisi geodinamikanya adalah keberadaan gunungapi bawah laut dan aktivitas

JURNAL KELAUTAN NASIONAL, Vol. 11, No. 1, April 2016, Hal 1- 10 
hidrotermal Potensi gunungapi bawah laut terungkap di perairan Sangihe-Talaud dengan ditemukan gunungapi Kawio Barat pada kedalaman 1890 meter yang memiliki cerobong hidrotermal yang berasosiasi dengan mineralisasi logam. Potensi semburan hidrotermal bawah laut (submarine geyser) terungkap di perairan dangkal Halmahera yang dapat dimanfaatkan untuk penggerak turbin pembangkit listrik berbasis aliran konveksi panas. Di dataran pasang surut, temperatur mata air panas mencapai $80-100^{\circ} \mathrm{C}$, sedangkan di bawah permukaan temperatur dapat mencapai $>200^{\circ} \mathrm{C}$ sehingga dapat dimanfaatkan untuk energi baru terbarukan berbasis panas bumi. Namun, disamping potensi sumber daya yang melimpah terdapat pula implikasi kebencanaan. Karena itu, kegiatan penelitian sumber daya dasar laut di Kawasan Timur Indonesia harus dibarengi dengan penelitian mitigasi potensi kebencanaan dan model adaptasinya.

\section{DAFTAR PUSTAKA}

Corbett, G.J and T.M Leach. 1996. Southwest Pacific Rim Gold-Copper SystemsStructure, Alteration, and Mineralization. Jakarta: Exploration Workshop, 51-56p.

Daly, M.C., B.D.G. Hooper and D.G. Smith. 1987. Tertiary Plate Tectonic and Basin Evolution in Indonesia. Proceedings Indonesia Petroleum Association. Sixteenth Annual Convention.

Hall, Robert. 2008. Continental Growth at the Indonesian margin of southeast Asia. Arizona Geological Society Diggest 22, p.245-258.

Hall, R. 2002. Kenozoic geological andplate tectonic evolution of SE Asia and SW Pasific: computer based reconstruction, model and animation. Journal of Asian Earth Sciences.

Halbach, P., L. Sarmili., M. Karg., B. Pracejus., B. Melchert., J. Post., E. Rahders and Y. Haryadi. 2003. The Break up of a Submarine Volcano in the FloresWetar Basin (Indonesia): Implication for Hydrothermal Mineral Deposits. Inter Ridge News Vol 12 (1), 18-22p.

Ira Dillenia, Rainer A. Troa, Eko Triarso. 2016.
Archaeological Remains Based on Geodynamic Conditions, Raja Ampat, Indonesia. Conservation and Management of Archaeological Sites (International Journal - terindex SCOPUS). Vol.18 No.1-3, p. 364- 371, 10 September 2016. ISSN: 1753-5522 (Online), 1350-5033 (Print), DOI: 10.1080/13505033.2016.1182775, http://dx.doi.org/10.1080/13505033.201 6.1182775

Makarim, S., P. Halbach., L. Sarmili., Mega F. Rosana., dan Rainer A. Troa. 2005. Mineralisasi Epitermal Sulfidasi Rendah dan Proses Hidrotermal di Daerah Cekungan Flores-Wetar. Majalah Geologi Indonesia, Vol. 20, No. 3, 165-173p.

Mc.Conachy., H. Permana and S. Burhanuddin. 2003. Indonesia-Australia Surveys for Submarine Hydrothermal Activity. Papers International Seminar on Marine and Fisheries. Jakarta: Agency of Marine and Fisheries Research.

Permana, H., B.Priadi., E. Triarso., Rainer A. Troa., S. Wirasantosa., B. Sulistiyo. 2012. The Deepsea Hydrothermal activities of Kawio Barat Volcano, Sangihe Island, North Sulawesi, Indonesia: Future Natural Resources. Presentation Slides. 1st ITB Geothermal Workshop 2012. Institut Teknologi Bandung, Bandung, Indonesia, unpublished.

Permana, H., T. Mc Conachy., I. Zulkarnaen., B. Priadi., J. Parr., N.D. Hananto., S. Burhanuddin., M. Pirlo dan I.S. Brodjonegoro. 2003. Gunungapi dan Hidrotermal Bawah Laut di Perairan Sulawesi Utara: Mineralisasi Bawah Laut dan Implikasi Tektonik. PIT ISOI. Jakarta.

Permana, Haryadi. 2002. Perkembangan Tektonik Kawasan Timur Indonesia. Prosiding Makalah Pelaksanaan Forum/Workshop Hasil Penelitian. Buku II Sumberdaya Nonhayati Laut. Jakarta: Pusat Riset Wilayah Laut dan Sumberdaya Nonhayati. Badan Riset Kelautan dan Perikanan.

Sarmili, L., P. Halbach., B. Pracejus., E. Rahders., S. Burhanuddin., S. Makarim., D. Purbani., G. Kusumah., J. Soesilo., J. Hutabarat., S.D. Johor and A. Mubandi. 2003. A New Prospect in Hydrothermal Mineralisation of the Baruna Komba 
Submarine Volcano in Flores-Wetar Sea, East Indonesia. Papers International Seminar on Marine and Fisheries. Jakarta: Agency of Marine and Fisheries Research.

Simandjuntak, T.O. 2004. Tektonika. Publikasi Khusus. Puslitbang Geologi. Bandung.

Troa, Rainer A. E. Triarso, I. Dillenia. 2013.

Kajian Sumber Daya Aktvitas Hidrotermal dan Lingkungan Laut Kawasan Halmahera Selatan. Laporan Akhir Penelitian, Puslitbang Sumberdaya Laut dan Pesisir Balitbang KP-KKP, unpublished.

Troa, Rainer A. E. Triarso, I. Dillenia. 2012. Kajian Sumber Daya Aktivitas Hidrotermal Kawasan Pesisir Barat Halmahera. Laporan Akhir Penelitian, Puslitbang Sumberdaya Laut dan Pesisir Balitbang KP-KKP, unpublished.

Triarso, E., Rainer A. Troa., I. Dillenia., N. Hasanah.2011. Kajian Morfostruktur dan Aktivitas Hidrotermal Kawasan Perairan Halmahera. Laporan Akhir Penelitian, Puslitbang Sumberdaya Laut dan Pesisir Balitbang KP-KKP, unpublished.

Triarso, E., Rainer Troa., S. Makarim., I. Dillenia., N. Hasanah., A.W. Widodo. 2010. Kajian Morfostruktur dan Aktivitas Hidrotermal Bawah Laut Kawasan Perairan Sangihe-Talaud, Sulawesi Utara. Laporan Akhir Kegiatan Riset T.A. 2010. Jakarta: Pusat Penelitian dan Pengembangan Sumberdaya Laut dan Pesisir. Badan Litbang Kelautan dan Perikanan. Kementerian Kelautan dan Perikanan, unpublished.

Troa, Rainer A., L. Sarmili. E. Triarso. 2009. Sebaran Batuan dan Potensi Mineralisasi Hidrotermal Gunungapi Bawah Laut Abangkomba, Perairan Flores-Wetar, Provinsi Nusa Tenggara Timur. Jurnal Segara Volume 5 Nomor 2 Hal 147-159, Jakarta Desember 2009; ISSN 1907-0659.

Troa, Rainer A., E. Triarso., J. Prihantono. 2007. Potensi Gunungapi Bawah Laut dan Aktivitas Hidrotermal Perairan Kawasan Timur Indonesia: Suatu Tinjauan Regional berdasarkan Teknik Pencitraan Tomografi Seismik. Ed: S.
Widiyantoro, L. Sarmili, A. Supangat. Pusris Wilayah Laut dan Pesisisir BRKP-DKP.

http://www.p3sdlp.litbang.kkp.go.id/index.ph p/en/data-a-informasi/866-satal-2010 